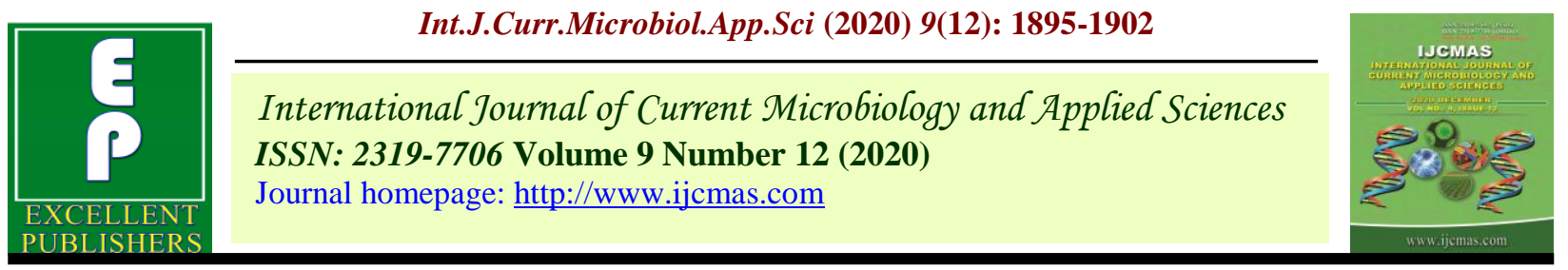

Original Research Article

https://doi.org/10.20546/ijcmas.2020.912.225

\title{
Evaluation of Strobilurin and Triazole Fungicides against Target Leaf Spot caused by (Corynespora cassiicola) in vitro Condition
}

\author{
Vivek Kumar Vishwakarma*, Moly Saxena and D. R. Saxena \\ Department of Plant Pathology, RVSKVV College of Agriculture, Sehore (M.P.), India \\ *Corresponding author
}

\section{A B S T R A C T}

\begin{tabular}{|l|}
\hline K e y w o r d s \\
Corynespora \\
cassiicola, \\
Strobilurin and \\
Triazole Fungicides \\
\hline Article Info \\
\hline $\begin{array}{l}\text { Accepted: } \\
\text { 14 November } 2020 \\
\text { Available Online: } \\
10 \text { December } 2020\end{array}$ \\
\hline
\end{tabular}

Target leaf spot caused by (Corynespora cassiicola). The most important fungal diseases of Soybean [Glycine max (L.) Merrill]. In vitro evaluation of eight fungicides at three concentrations viz. 50 ppm, 100ppm and 200 ppm. Mix fungicides viz., prochloraz + tebuconazole, azoxystrobin + tebuconazole + prochloraz, pyraclostrobin + mefentrifluconazole + fluxapyroxad, carbendazim + mancozeb and hexconazole, completely inhibited the growth of $C$. cassiicola, at lower concentration of 50ppm. At $100 \mathrm{ppm}$, tebuconazole + sulphur reduced the growth of $C$. cassiicola $73 \%$, tebuconazole $61.21 \%$ and pyraclostrobin $51.71 \%$. With the increase of concentration to $200 \mathrm{ppm}$, tebuconazole + sulphur reduced $82.89 \%$ mycelial growth, tebuconazole $79.08 \%$ and pyraclostrobin $70.34 \%$.

\section{Introduction}

Soybean [Glycine max (L.) Merrill] is a legume crop and is the second largest after groundnut oilseed in India. It is growing in diverse agro-climatic conditions. Soybean ranks first among the oilseeds in the world and contributes for nearly $25 \%$ of the world's total oil and fats production. The USA leads in terms of area and production of soybean, while India ranks fourth in area and fifth in production in the world. USA, Argentina, Brazil, China and India are the major producers of soybean accounting for 90 percent of world production. Productivity of soybean in India $(830 \mathrm{~kg} / \mathrm{ha})$ is less than global $(2800 \mathrm{~kg} / \mathrm{ha})$ average due to abiotic and biotic stresses (Anno, 2019).
Strobilurins are an important class of fungicides that come from the discovery of Stroblilurus tenacellus, the mushroom fungus that causes wood-rotting. This isolated natural fungicide is thought to be used to protect the fungus against microbes in the decomposition of the wood. The discovery of strobilurins led scientist to isolate and produce synthetic strobilurins by chemically altering the compound to be able to tolerate sunlight (Vincelli, 2012).

Mix fungicides, pyraclostrobin + epoxiconazole, Azoxystrobin + cyproconazole, pyraclostrobin + epoxiconazole + fluxapyroxad and procymidone showed significant reduction in mycelial growth with increased rates of 
fungicides from 10 and $100 \mathrm{mg}$ for all isolates of C.cassicola (Cabral et al., 2016).The inhibitory concentration (IC50) studies for different fungicides specific to $C$. cassiicola in soybean are scarce, yet it is very useful in carrying out research and sensitivity monitoring, especially in areas where the control of this disease is not being efficient (Avozani et al., 2014).

\section{Materials and Methods}

The laboratory experiments were carried out at the Department of Plant Pathology, R.A.K. College of Agriculture, Sehore (M.P.).

\section{Isolation, purification and identification of pathogen}

Small pieces of infected tissue $(2-3 \mathrm{~mm}$ in length) target leaf spot were cut at the junction of diseased and healthy portion with the help of disinfected blade after surface sterilizing with alcohol. These bits were surface sterilized in 0.1 per cent mercuric chloride solution $\left(\mathrm{HgCl}_{2}\right)$ for 30 seconds followed by three washing with sterilized distilled water in Petri plates under aseptic conditions using laminar air flow. These bits were then dried by placing on sterilized blotting paper. Five bits were transferred aseptically to the sterile Petri plates containing potato dextrose agar (PDA) medium. Inoculated Petri plates were incubated at $25 \pm 2^{\circ} \mathrm{C}$ for five to seven days and examined at frequent intervals to see the growth of the fungus/conidia developing from different pieces. (Ahmad et al., 2013)

The appearing fungus (Corynespora cassiicola) was observed after 72 hours and isolations were made from developing colonies for further study. The pathogen was further purified by hyphal tip method and subcultured on PDA slants kept at $4{ }^{\circ} \mathrm{C}$ for further study (Dhingra and Sinclair,1985).
Isolated fungus (Corynespora cassiicola) was identified according to morphological characters and cultural behaviour (Ellis and Subramanian, 1971).

\section{In vitro evaluation of fungicides}

The poison food technique (Nene and Thapliyal, 1979) was followed to evaluate the efficacy of fungicides in inhibiting the mycelial growth of Corynespora cassiicola. Strobilurin and Triazole fungicides used in the present investigation are three concentrations i.e., 50ppm, 100ppm, 200ppm of each fungicides were used. Three replications were kept for each concentration. Corynespora cassiicola was grown on PDA medium for 15 days prior to setting up the experiment. The PDA medium was prepared and melted. Required quantity of fungicides was added to the melted medium to obtain the required concentration on the basis of active ingredient present in the chemical. Little amount of streptomycin was added in each flask before plating to avoid bacterial contamination. Twenty $\mathrm{ml}$ of poisoned medium was poured in each sterilized Petri plates. Suitable check was maintained without addition of fungicides. The plates were then inoculated as described earlier and incubated at $25 \pm 1{ }^{\circ} \mathrm{C}$. The mycelium growth as colony diameters was measured after 3 days, 6 days and 9 days of inoculation. The inhibition percentage of each fungicide on Corynespora cassiicola was determined by using the formula given by Vincent (1947).

$\mathrm{I}=\frac{\mathrm{C}-\mathrm{T}}{\mathrm{C}} \times 100$

Where,

$\mathrm{I}=$ Per cent inhibition in growth of test pathogen

$\mathrm{C}=$ Radial growth $(\mathrm{mm})$ in control

$\mathrm{T}=$ Radial growth $(\mathrm{mm})$ in treatment 


\section{Results and Discussion}

Evaluation of strobilurin and triazole fungicides against caused by $\boldsymbol{C}$. cassiicola in vitro condition

In vitro radial growth of Corynespora cassiicola was recorded by poison food technique using eight fungicides at three concentrations viz. 50ppm, 100ppm and 200ppm (Plate-1\& 2). The data presented in the table $1,2 \& 3$ and fig. $1,2 \& 3$ indicates that the growth of $C$. cassiicola was significantly inhibited at 50ppm, $100 \mathrm{ppm}$, and $200 \mathrm{ppm}$ concentrations of fungicides as compared to control.

Table.1 Radial growth of Corynespora cassiicola at 50ppm concentration of fungicides

\begin{tabular}{|c|c|c|c|c|c|}
\hline \multirow{2}{*}{$\begin{array}{c}\text { S } \\
\text {.No }\end{array}$} & \multirow[b]{2}{*}{ Treatment } & \multicolumn{3}{|c|}{ Mean radial growth $(\mathrm{mm}) *$ on } & \multirow{2}{*}{$\begin{array}{c}\text { Final } \\
\text { Inhibition } \\
(\%)\end{array}$} \\
\hline & & $3^{\text {rd }}$ day & $6^{\text {th }}$ day & $9^{\text {th }}$ day & \\
\hline 1 & Pyraclostrobin & 14.33 & 25.00 & 61.00 & 30.42 \\
\hline 2 & Tebuconazole & 11.33 & 20.66 & 42.33 & 51.71 \\
\hline 3 & Prochloraz + Tebuconazole & 0.00 & 0.00 & 0.00 & 100 \\
\hline 4 & Azoxystrobin + Tebuconazole + Prochloraz & 0.00 & 0.00 & 0.00 & 100 \\
\hline 5 & $\begin{array}{l}\text { Pyraclostrobin + Mefentrifluconazole+ } \\
\text { Fluxapyroxad }\end{array}$ & 0.00 & 0.00 & 0.00 & 100 \\
\hline 6 & Tebuconazole + Sulphur & 7.66 & 14.33 & 28.66 & 67.30 \\
\hline 7 & Carbendazim + Mancozeb & 0.00 & 0.00 & 0.00 & 100 \\
\hline 8 & Hexaconazole & 0.00 & 0.00 & 0.00 & 100 \\
\hline \multirow[t]{3}{*}{9} & Control & 46.33 & 77.66 & 87.66 & - \\
\hline & $\mathrm{SE}(\mathrm{m}) \pm 1$ & 0.40 & 0.43 & 0.49 & _ \\
\hline & CD at $5 \%$ & 1.20 & 1.28 & 1.48 & _ \\
\hline
\end{tabular}

*Average of three replications

Table.2 Radial growth of Corynespora cassiicola at 100ppm concentration of fungicides

\begin{tabular}{|c|c|c|c|c|c|}
\hline \multirow{2}{*}{$\begin{array}{l}\text { S. } \\
\text { No }\end{array}$} & \multirow[b]{2}{*}{ Treatment } & \multicolumn{3}{|c|}{ Mean radial growth $(\mathrm{mm}) *$ on } & \multirow{2}{*}{$\begin{array}{c}\text { Final } \\
\text { Inhibition } \\
(\%)\end{array}$} \\
\hline & & $3^{\text {rd }}$ day & $6^{\text {th }}$ day & $9^{\text {th }}$ day & \\
\hline 1 & Pyraclostrobin & 12.33 & 24.00 & 42.33 & 51.71 \\
\hline 2 & Tebuconazole & 10.33 & 18.00 & 34.00 & 61.21 \\
\hline 3 & Prochloraz + Tebuconazole & 0.00 & 0.00 & 0.00 & 100 \\
\hline 4 & Azoxystrobin + Tebuconazole +Prochloraz & 0.00 & 0.00 & 0.00 & 100 \\
\hline 5 & $\begin{array}{l}\text { Pyraclostrobin+Mefentrifluconazole+ } \\
\text { Fluxapyroxad }\end{array}$ & 0.00 & 0.00 & 0.00 & 100 \\
\hline 6 & Tebuconazole + Sulphur & 5.66 & 12.33 & 23.66 & 73.00 \\
\hline 7 & Carbendazim + Mancozeb & 0.00 & 0.00 & 0.00 & 100 \\
\hline 8 & Hexaconazole & 0.00 & 0.00 & 0.00 & 100 \\
\hline \multirow[t]{3}{*}{9} & Control & 46.33 & 77.66 & 87.66 & - \\
\hline & $\mathrm{SE}(\mathrm{m}) \pm 1$ & 0.31 & 0.41 & 0.47 & - \\
\hline & CD at $5 \%$ & 1.05 & 1.24 & 1.41 & - \\
\hline
\end{tabular}

*Average of three replications 
Table.3 Radial growth of Corynespora cassiicola at 200ppm concentration of fungicides

\begin{tabular}{|c|c|c|c|c|c|}
\hline \multirow{2}{*}{$\begin{array}{l}\text { S } \\
\text {.No }\end{array}$} & \multirow[b]{2}{*}{ Treatment } & \multicolumn{3}{|c|}{ Mean radial growth $(\mathrm{mm}) *$ on } & \multirow{2}{*}{$\begin{array}{c}\text { Final } \\
\text { Inhibition }(\%)\end{array}$} \\
\hline & & $3^{\text {rd }}$ day & $6^{\text {th }}$ day & $9^{\text {th }}$ day & \\
\hline 1 & Pyraclostrobin & 11.00 & 17.33 & 26.00 & 70.34 \\
\hline 2 & Tebuconazole & 8.00 & 14.66 & 18.33 & 79.08 \\
\hline 3 & Prochloraz + Tebuconazole & 0.00 & 0.00 & 0.00 & 100 \\
\hline 4 & Azoxystrobin + Tebuconazole + Prochloraz & 0.00 & 0.00 & 0.00 & 100 \\
\hline 5 & $\begin{array}{l}\text { Pyraclostrobin + Mefentrifluconazole+ } \\
\text { Fluxapyroxad }\end{array}$ & 0.00 & 0.00 & 0.00 & 100 \\
\hline 6 & Tebuconazole + Sulphure & 4.00 & 10.33 & 15.00 & 82.89 \\
\hline 7 & Carbendazim + Mancozeb & 0.00 & 0.00 & 0.00 & 100 \\
\hline 8 & Hexaconazole & 0.00 & 0.00 & 0.00 & 100 \\
\hline \multirow[t]{3}{*}{9} & Control & 46.33 & 77.66 & 87.66 & - \\
\hline & $\mathrm{SE}(\mathrm{m}) \pm 1$ & 0.29 & 0.35 & 0.36 & - \\
\hline & CD at $5 \%$ & 0.88 & 1.05 & 1.10 & _- \\
\hline
\end{tabular}

*Average of three replications

Fig.1 Mycelial growth of Corynespora cassiicola at 50ppm concentration of different fungicides

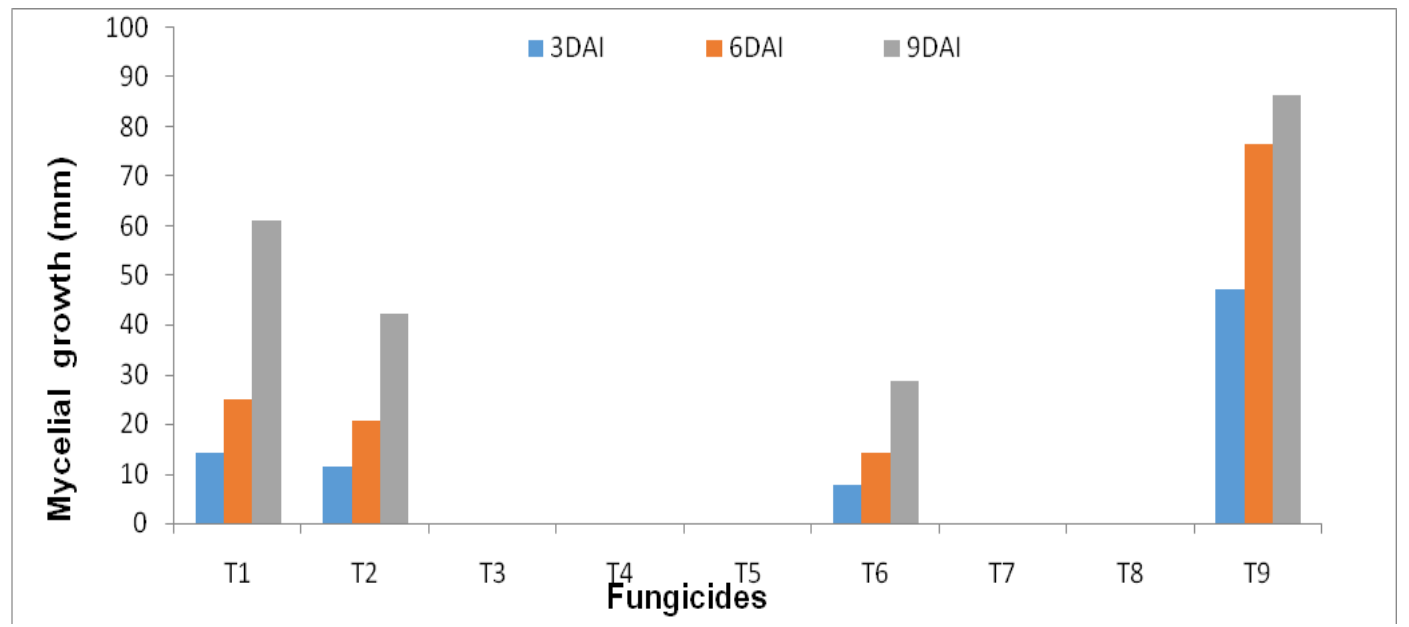

\footnotetext{
$\mathrm{T}_{1}-$ Pyraclostrobin

$\mathrm{T}_{2}$ - Tebuconazole

$\mathrm{T}_{6}-$ Tebuconazole+ Sulphur

$\mathrm{T}_{3}$ - Prochloraz+Tebuconazole

$\mathrm{T}_{7}-$ Carbendazim+ Mancozeb

$\mathrm{T}_{4}-$ Azoxystrobin+ Tebuconazole+ Prochloraz $\quad \mathrm{T}_{9}-$ control

$\mathrm{T}_{5}-$ Pyraclostrobin+ Mefentrifluconazole+ fluxapyroxad
} 
Fig.2 Mycelial growth of Corynespora cassiicola at 100ppm concentration of different fungicides

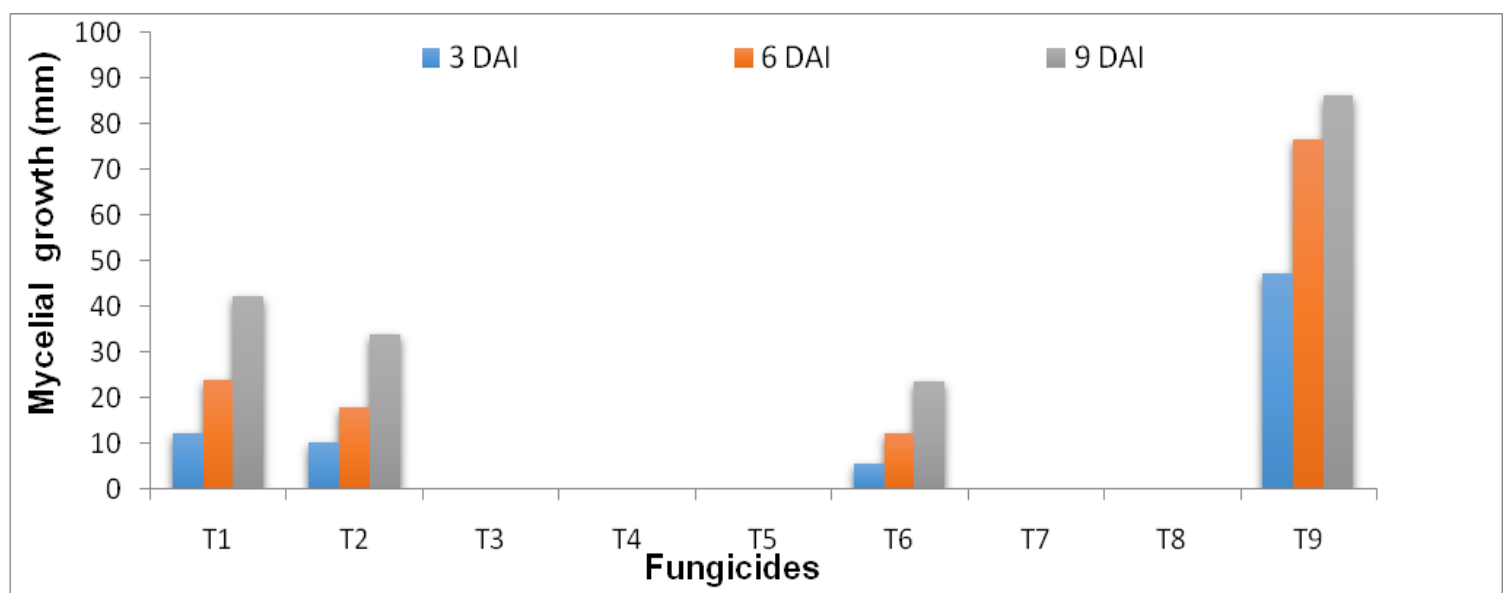
$\mathrm{T}_{1}-$ Pyraclostrobin
$\mathrm{T}_{2}$ - Tebuconazole
$\mathrm{T}_{6}-$ Tebuconazole+ Sulphur
$\mathrm{T}_{3}$ - Prochloraz+Tebuconazole $\mathrm{T}_{7}-$ Carbendazim+ Mancozeb
- Azoxystrobin+ Tebuconazole+ Prochloraz $\mathrm{T}_{9}-$ control
$\mathrm{T}_{5}-$ Pyraclostrobin+ Mefentrifluconazole+ fluxapyroxad

Fig.3 Mycelial growth of Corynespora cassiicola at 200ppm concentration of different fungicides

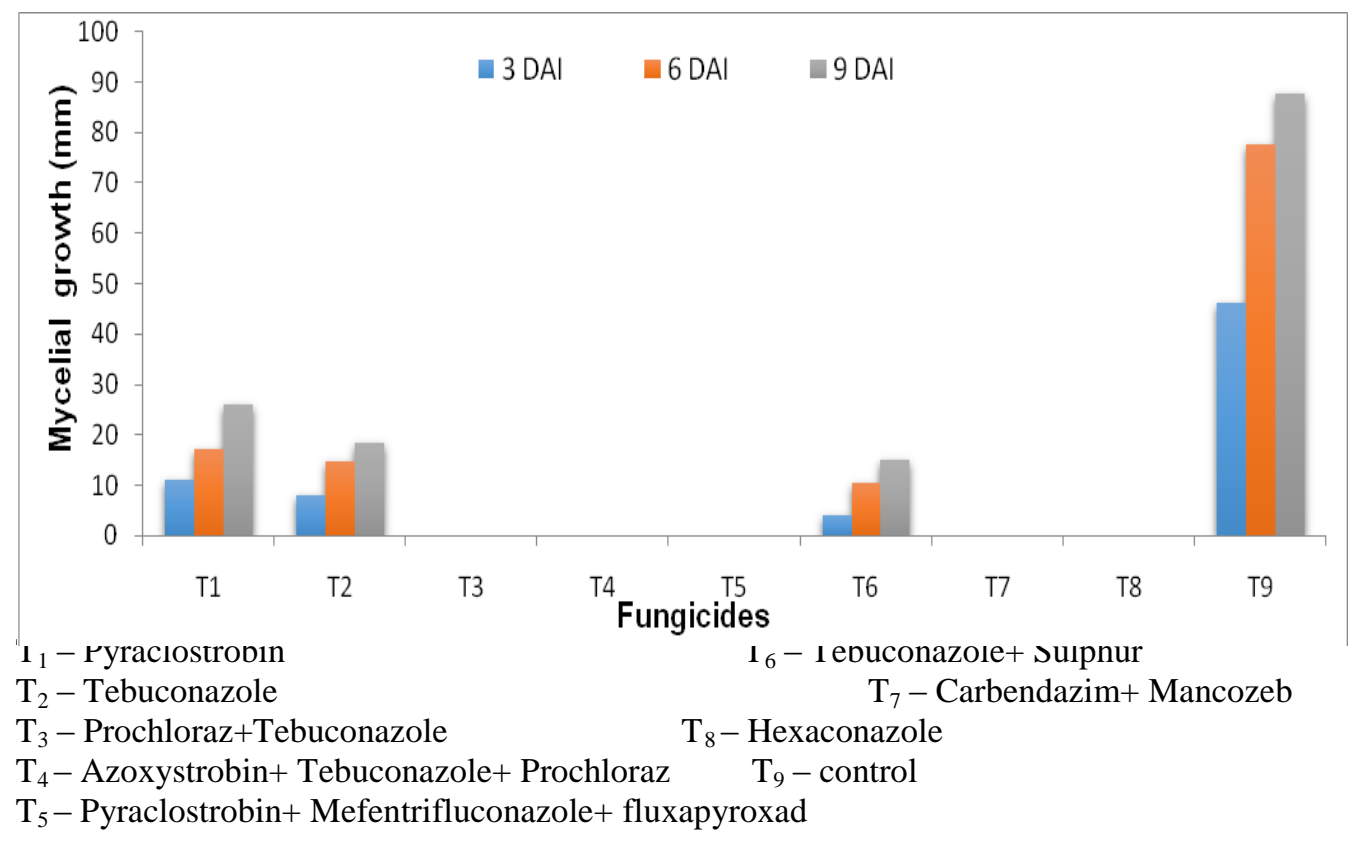


Plate.1 Mycelial growth of Corynespora cassiicola at 50ppm, 100ppm, 200ppm concentration of different fungicides

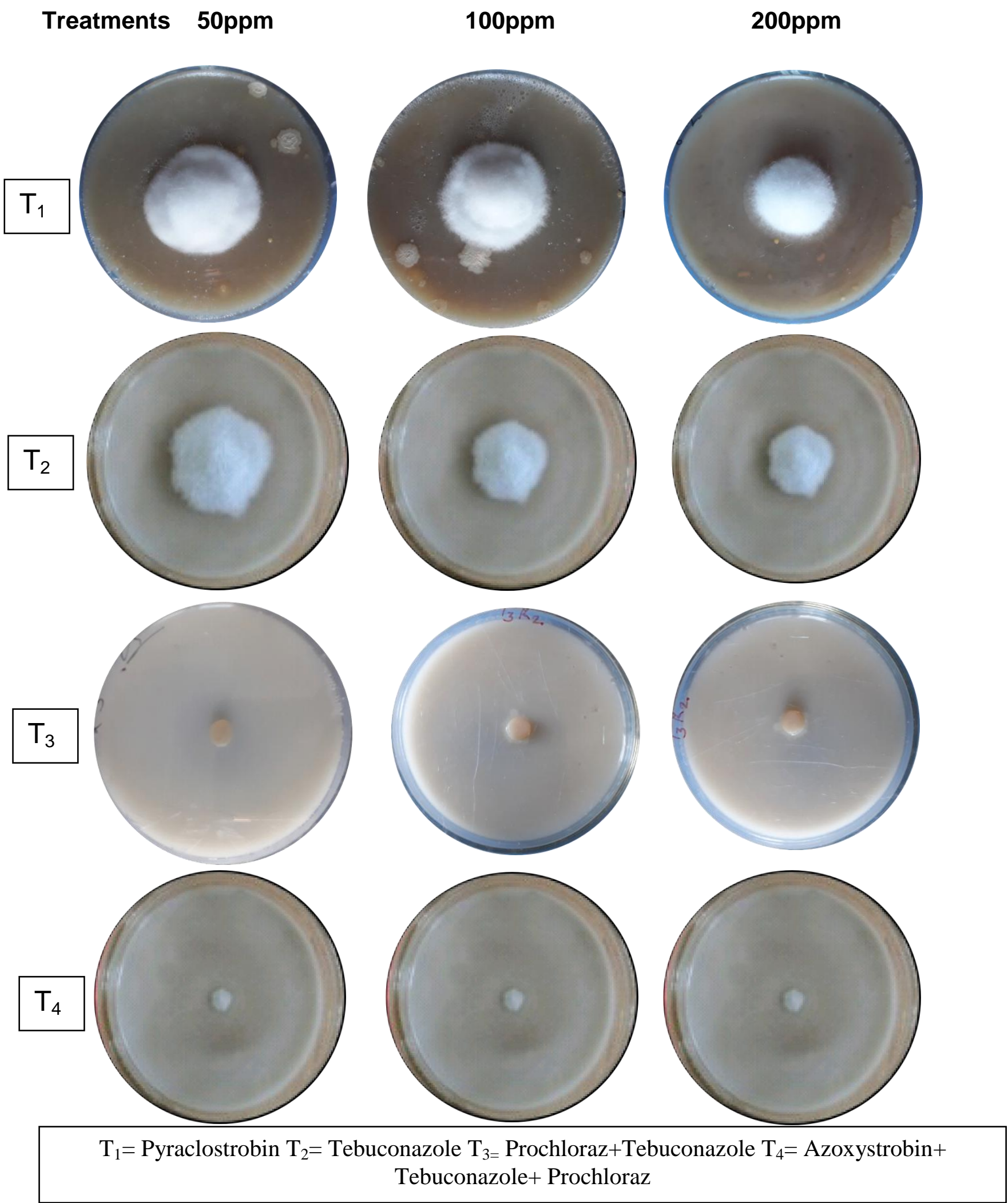


Plate.2 Mycelial growth of Corynespora cassiicola at 50ppm, 100ppm, 200ppm concentration of different fungicides

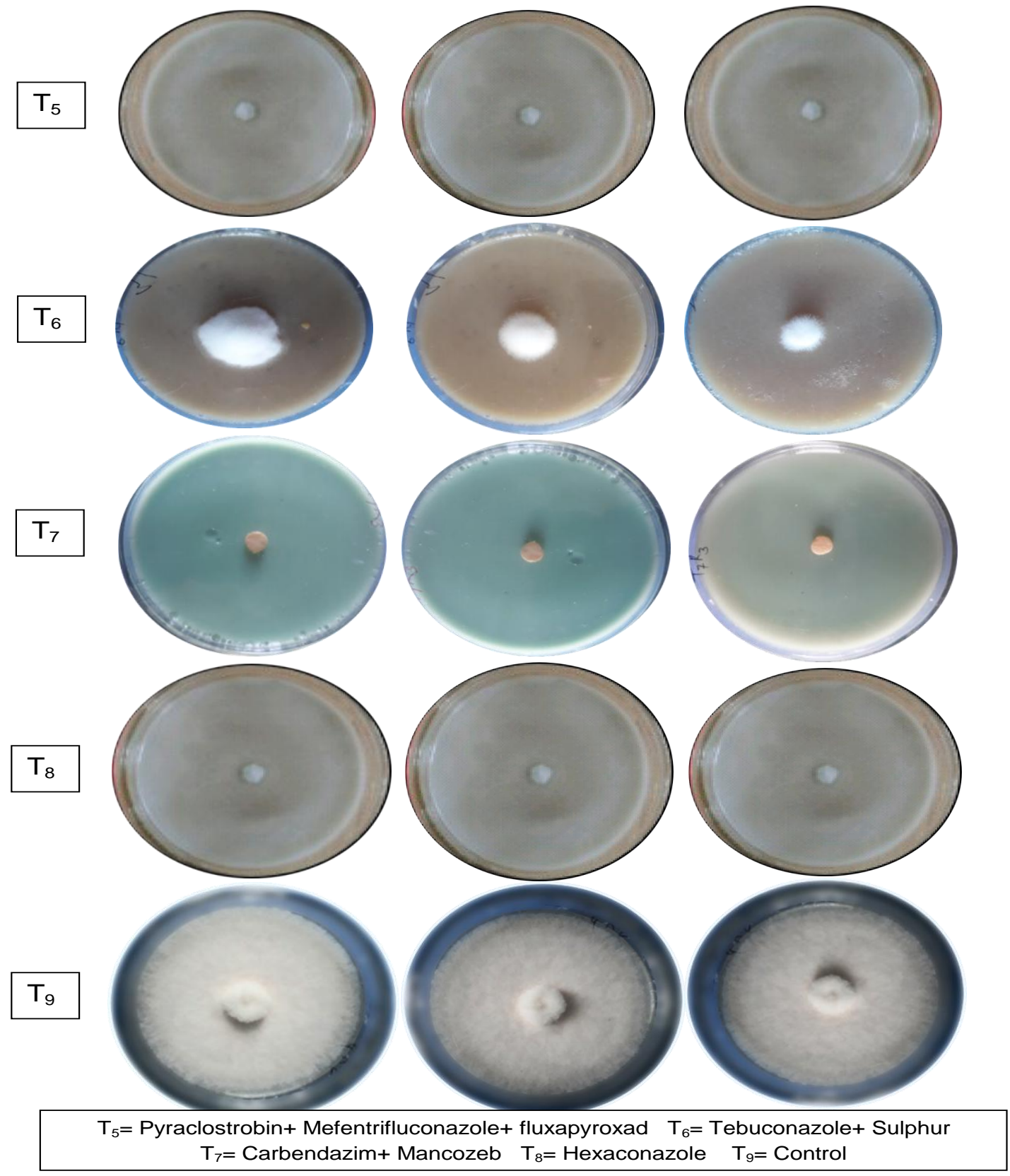

In the present investigation, mix fungicides viz., prochloraz + tebuconazole, azoxystrobin + tebuconazole + prochloraz, pyroclostrobin + mefentrifluconazole $\quad+$ fluxapyroxad, carbendazim + mancozeb and hexconazole, completely inhibited the growth of $C$. cassiicola, at lower concentration of $50 \mathrm{ppm}$.
At 100ppm, Tebuconazole + sulphure reduced $73 \%$, tebuconazole $61.21 \%$ and Pyraclostrobin $51.71 \%$. With the increase of concentration to $200 \mathrm{ppm}$, Tebuconazole + sulphur reduced $82.89 \%$ mycelia growth, tebuconazole $79.08 \%$ and Pyraclostrobin $70.34 \%$. 
Cabral et al., (2016), also demonstrated that mix fungicides, pyraclostrobin + epoxiconazole, Azoxystrobin + cyproconazole, pyraclostrobin + epoxiconazole + fluxapyroxad and procymidone significantly reduced mycelial growth of C.cassiicola with increase rates of fungicides from 10 and $100 \mathrm{mg}$. Similarly in 2014, Aozani found Tebuconazole at 1.89 $\mathrm{mg} / \mathrm{l}$ inhibiting the mycelial growth by $50 \%$.

Kurre et al., (2017) reported complete inhibition of C. cassiicola by fungicides fluxapyroxad, propiconazole, tebuconazole and hexaconazole and minimum inhibition of mycelial growth was recorded by mancozeb $(30.59 \%)$ and pyraclostrobin $(75.37 \%)$.

\section{References}

Ahmed, F.A., Alam, N. and Khair, A. 2013. Incidence and biology of Corynespora cassiicola (berk. \& curt.) wei. disease of okra in Bangladesh. Bangladesh J. Bot., 42 (2): 265-272.

Anonymous 2019. Online Agriculture Statics. Http/www.faostal.org.

Avozani, A., Reis, E.M. and Tonin, R.B. 2013. Sensitivity loss by Corynespora cassiicola, isolated from soybean, to the fungicide carbendazim. Summa Phytopathol., 40(2): 273-276.

Cabral, W.C.; Campos, H. D.; Costa, L. S. A.
S. and Simon, G. A. 2016. In vitro susceptibility of Corynespora cassiicola isolate from Brazil fields to fungicide. Afr. J. Agric. Res, Vol. 11(19), pp: 1699-1711.

Dhingra, O.D. and Sinclair, J.B. 1985. "Culture of Pathogens," Basic Plant Pathology Methods, CRC Press, Boca Raton, pp: 11-47.

Ellis, M. B. and Holiday, P. 1971. Corynespora cassiicola (Berk. \&Curt.) Wei. Common wealth Mycological Institute Descriptions of Fungi and Bacteria, 31: 303.

Kurre, A. K.; Dewangan, M. and Dantre, R.K. 2017. Evaluation of fungicides against Target leaf spot caused by Corynespora cassiicola in vitro condition. Int. J. Curr. Microbiol. App. Sci. 6(8): 462-467

Nene, Y.L. and Thapliyal, P.N. 1979. Fungicides in plant disease control. Oxford and JBH Publishing Co., New Delhi. pp: 413.

Vincelli, P. 2012. QoI (Strobilurin) Fungicides: Benefits and Risks. APS net Features.doi:10.1094/PHI-I-20020809-02.

Vincent, J. M. 1947. Distribution of fungal hyphae in per cent of certain inhibitors Nature, 96: 596.

\section{How to cite this article:}

Vivek Kumar Vishwakarma, Moly Saxena and Saxena, D. R. 2020. Evaluation of Strobilurin and Triazole Fungicides against Target Leaf Spot caused by (Corynespora cassiicola) in vitro Condition. Int.J.Curr.Microbiol.App.Sci. 9(12): 1895-1902.

doi: https://doi.org/10.20546/ijcmas.2020.912.225 